日臨外会誌 $59(1), 226-230,1998$

症例

低血糖症状を伴った大網原発肉腫の 1 例

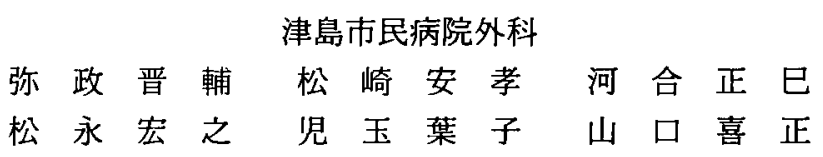

症例は75葴男性．低血糖症状と腹部腫瘤を主訴に入院した。種々の検査で肝転移を伴 う大網腫瘍と診断し，手術を施行した。病理組織学的には分化傾向に乏しい大網原発の 肉腫, およびその肝転移と診断された. 術後約 1 年 5 力月, 著明な腹膜播種のため死亡 した，過去 16 年間の大網悪性腫湟の本邦報告例は自験例を含め60例であり，診断には血 管造影が有用であった。また腹膜播種の出現頻度は $44.1 \%$ と高率であった. 自験例では， 血中 IGF-II を含め内分泌学的な異常を認めなかったが腫瘍内の IGF-II は未解析であ り，腫場性低血糖に IGF-II が関与していた可能性は否定できない。

索引用語：大網腫瘍, 大網肉腫, 腫場性低血糖

はじめに

大網原発腫湯は従来まれな疾患とされてきたが，画 像診断の発達とともに近年その報告例は增加傾向にあ る.しかしながら，良悪性の鑑別や質的診断の難しさ， また悪性腫場であった場合の予後の厳しさなど，その 診断と治療に大きな問題点の残る疾患群である122. 。 れわれは著明な低血糖症状で発症した大網原発肉腫の 1 例を経験したので，本邦報告例の累積結果と共に報 告する.

\section{症例}

症例：75歳, 男性.

主訴：腹部腫瘤, 低血糖発作.

現病歴：約10年前より腹部腫瘤を指摘されていたが 放置. 1995年6月23日より毎朝低血糖症状が発現し, 6 月28日に緊急入院となった。

既往歴: 脳梗塞 (65歳).

家族歴：特記すべきことなし。

入院時現症：身長 $157 \mathrm{~cm}$ ，体重 $49 \mathrm{~kg}$ ，腹部全体を占 める凹凸不整な硬い腫瘤を触知した。

入院時検查所見 : $\mathrm{Hb} 8.7 \mathrm{~g} / \mathrm{dl}, \mathrm{FBS} 29 \mathrm{mg} / \mathrm{dl}$ であ り軽度の筫血と著明な低血糖を認めた. $75 \mathrm{~g}$ の経口糖 負荷試験では 1 時間値 $130 \mathrm{mg} / \mathrm{dl}, 2$ 時間值 $197 \mathrm{mg} / \mathrm{dl}$ とむしろ耐糖能の低下を示し，この間の血中インスリ ン値は9〜 $16 \mu \mathrm{U} / \mathrm{ml}$ と低值であった。また CEA,

1997年 6 月 13日受付 1997年 8 月21日採用
CA19-9はともに正常であった。

画像診断：腹部 CT 検査では腹腔全体を占める巨大 腫瘤を認め，辺緑は凹凸不整であり中心壊死を伴って いた（図 1 上)。また肝 $\mathrm{S} 8$ に直径 $3 \mathrm{~cm}$ 大の転移と思わ れる腫瘤が描出された (図 1 下). 腹部血管造影検査で は右胃大網動脈分枝の著明な進展と血管増生を認めた (図 2 )。上部消化管造影および注腸検査では腫瘤によ る圧排所見のみであった。以上より肝転移を有する大 網原発の腫瑒，特に平滑筋肉腫を疑い，7月12日手術 を施行した。

手術所見：腫崵は一部大網に被われ，表面には怒張 した血管が多数認められた。胃と横行結腸は腫瘍によ り圧排されていたが剥離は容易であり，横行結腸間膜 との連続性もなかった.また腹膜播種の所見も全く認 められなかった. 腫場摘出と肝 S8部分切除を施行し た. 手術時間は 2 時間56分, 出血量は $270 \mathrm{~g}$ であった.

摘出標本所見：腫瘍は $24 \times 24 \times 15 \mathrm{~cm}, 3,900 \mathrm{~g}$ と巨 大であり，割面では分葉状を呈し，中心部には小さな 石灰化像も認められた。肝転移巣は直径 $3 \mathrm{~cm}$ 大の類円 形で一部壊死を伴っていた（図 3).

病理組織学的所見：クロマチンに富んだ類円形の核 を有する腫瘍細胞の増殖は上皮性配列を示さず, 非常 に核分裂像に富んでいた(図 4). しかし光顕学的に腫 瘍の起源を特定することはできなかった，免疫染色で はS-100, NSE, vimentin, keratin, smooth muscle actin, $\alpha 1$-anti-trypsin にいずれも陰性であり, 腫瘍細 

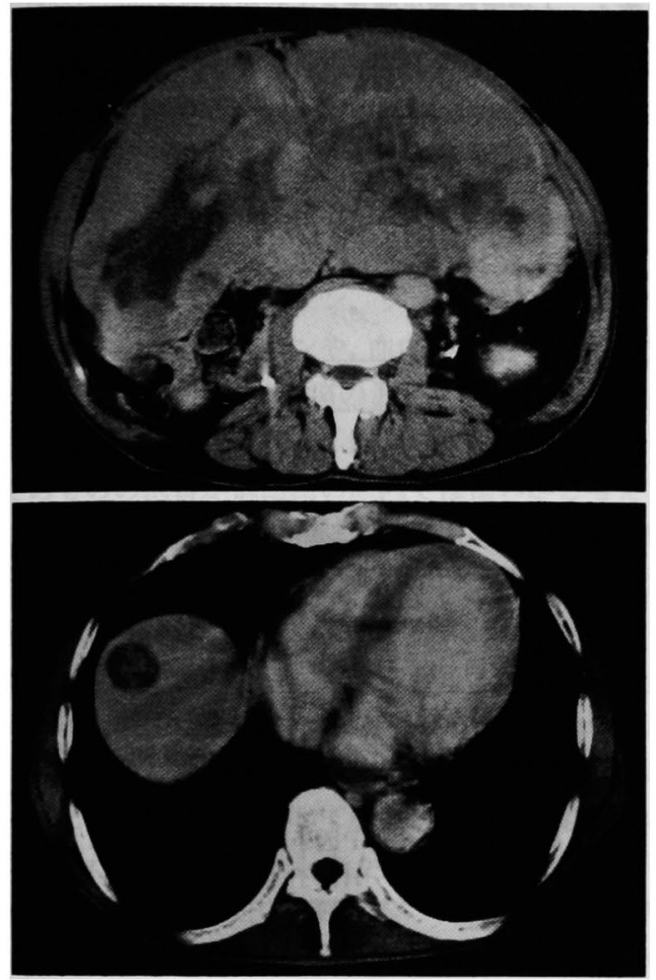

图 1 腹部 CT：(上段) 腹腔全域を占める腫瘤を認 めた。(下段）肝 S8に円形の腫瘤を認めた。

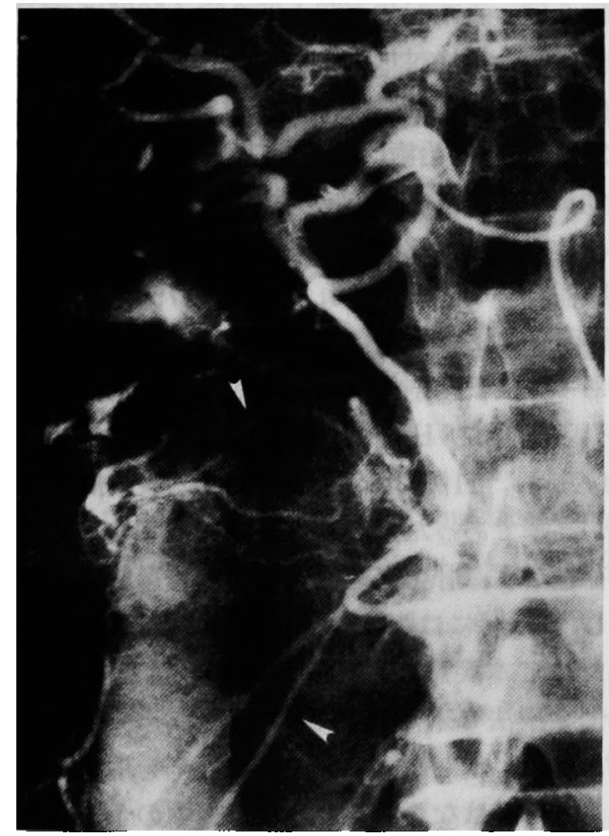

図 2 腹腔動脈造影：右胃大網動脈分枝の著明な進展 と血管增生を認めた（矢頭)。
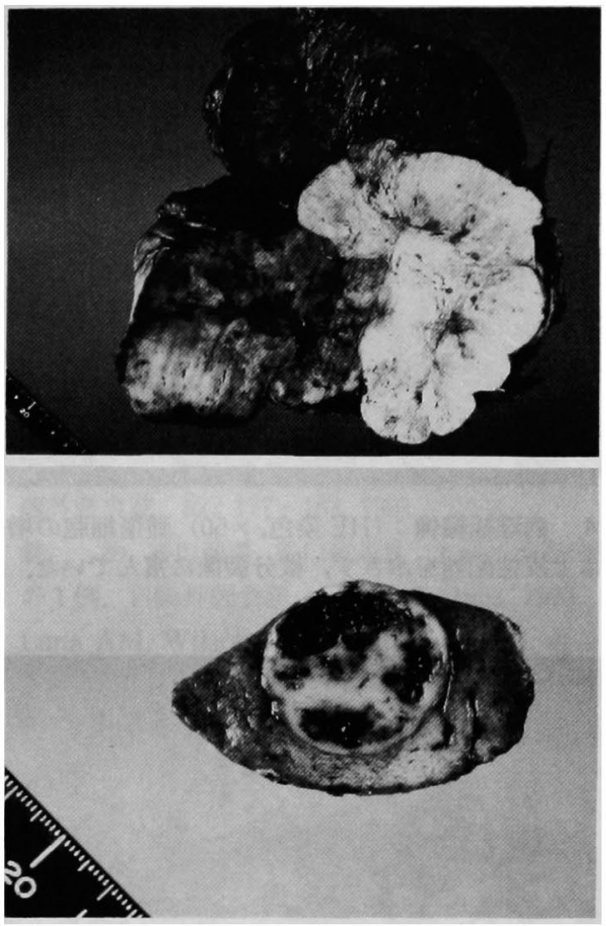

図 3 摘出標本：(上段) 大網腫瘍の割面. 白色, 赤褐 色などの種々の色調の混在した分葉状を呈してい た. (下段) 肝 S8転移巣の割面. 類円形で壊死部分を 混在していた.

胞の分化傾向は不明であった．肝転移巣も同様の所見 であった．以上より肝転移を伴う大網原発の, 分化傾 向に乏しい肉腫と診断した.

術後経過：術後経過は良好で低血糖症状は全く消失 し第16病日に軽快退院した。しかし翌1996年 5 月頃か ら再び低血糖症状が出現し再入院となった. CT 検查 で多発性肝転移掞よび腹膜播種が明らかとなり CHOP 療法 4 回, CDDP.5FU 療法 2 回施行したがい ずれも低血糖症状のわずかな改善を見たのみで画像上 は $\mathrm{NC}$ もしくは PDであり, 術後 1 年 5 カ月で死亡し た。またこの経過中に測定した尿中C-ペプタイドは $26.7 \mu \mathrm{g} / \mathrm{l}$, 血中ソマトスタチンは $5.7 \mathrm{pg} / \mathrm{ml}$, IGF-II (insulin-like growth factor II) は690ng/ml であった。 さらに血中 ACTH およびコルチソールも正常であり 内分泌上の異常は認められなかった。

剖検所見：腹曌全域を占める白色大豆大の腹膜播種 による結節を認めた（図 5)。また多発性肝転移も認め たが，この他の臓器への転移，浸潤はなかった。 


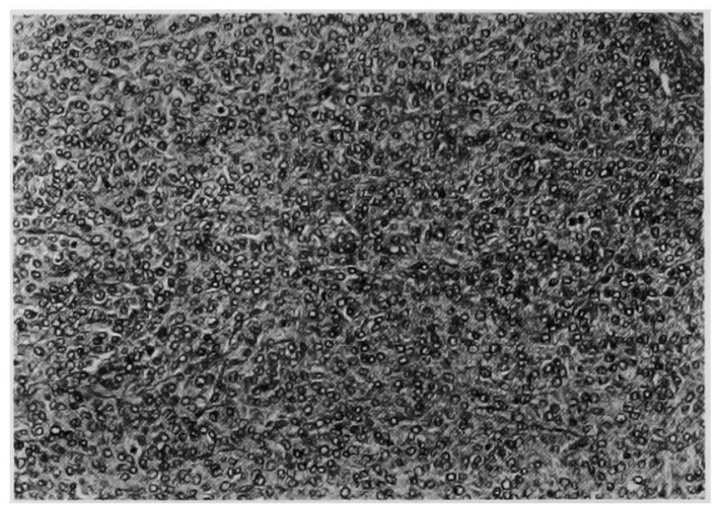

図4 病理組織像：(HE 染色, $\times 50)$ 腫瘍細胞の増殖 は上皮性配列を示さず，核分裂像に富んでいた。

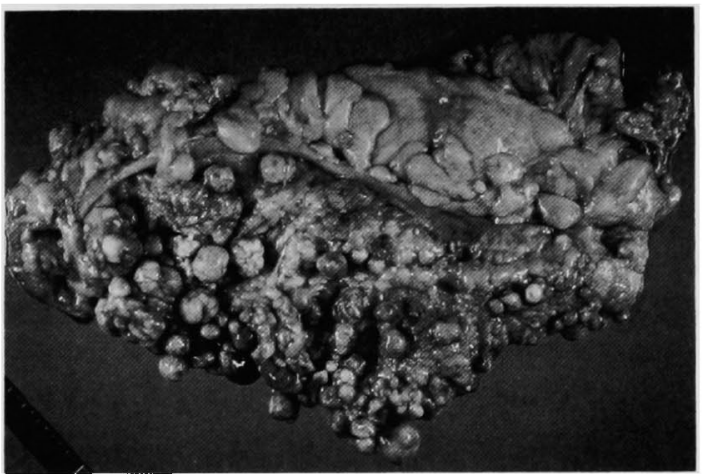

図 5 剖検所見：腹腔全域にわたり白色大豆大の腹膜 播種結節を認めた。

\section{考察}

1980年から1995年までの16年間に本邦で論文報告さ れた大網原発悪性腫瘍は59例でありこれに本症例を 加えて検討した。平滑笳肉腫が27例 $(45 \%$ ） と最も多 く存在した(表 1)，男女比は $3 ： 2$ と男性に多く，50 歳代に最も多く発生し平均年歯は52.2歳であった。腫 演重量は $40 \mathrm{~g}^{3 \prime}$ から $6,000 \mathrm{~g}^{4)}$ と多様であり平均 $1,756 \mathrm{~g}$ であった。主訴では全体の約 8 割が腫瘤触知し，腹痛 と腹部膨満感がそれぞれ 3 割を占めた（表 2 )。また腫 瘤触知のみで他の症状を全く伴わなかった症例は18例 (30\%)であった大網腫瘍であることの診断は血管造 影, CT, 穿刺細胞診により全体の66.7\%に可能であっ たが，特に血管造影の施行された 36 例中32例(88.9\%) で大網腫瘍と正診されてており，血管造影が診断上有用 であると考えられた(表 2)。また開腹して初めて診断 された症例が 9 例 (15\%)，剖検で診断された症例が 4
表 1 大網原発覀性腫瘍の本邦報告例(1980-1995)

\begin{tabular}{|c|c|}
\hline 平滑筋肉腫 & 27例 \\
\hline 悪性線維性組織球腫(MFH) & 9例 \\
\hline 平滑筋芽細胞喢 & 8例 \\
\hline 恶性腹膜中皮腫 & 5例 \\
\hline 脂肪肉腫 & 3例 \\
\hline 線維肉腫 & 2例 \\
\hline 愍性神経䩪䛲 & 2例 \\
\hline その他 & 4例* \\
\hline 計 & 60例 \\
\hline
\end{tabular}

表 2 大網悪性腫瘍60例の検討

\begin{tabular}{|c|c|}
\hline 主訴：腹部腫瘤 & $47 / 60(78.3 \%)$ \\
\hline 腹痛 & $20 / 60(33.3 \%)$ \\
\hline 腹部膨満 & $20 / 60(33.3 \%)$ \\
\hline \multirow{2}{*}{ 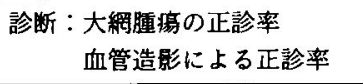 } & $40 / 60(66.7 \%)$ \\
\hline & $32 / 36(88.9 \%)$ \\
\hline \multirow{3}{*}{ 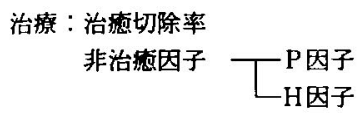 } & $27 / 53(50.9 \%)$ \\
\hline & $18 / 53(34.0 \%)$ \\
\hline & $7 / 53(13.2 \%)$ \\
\hline
\end{tabular}

例 $(6.7 \%)$ 存在した。しかしながらその質的診断は難 しく,術前に質的診断がなされたものは池田ら ${ }^{5)}$, 岸本 $ら^{6}$ の症例 2 例のみ（3.3\%）という現状である。

剖検 6 例，手術記載不明 1 例を除く53例について手 術所見について検討した. 開腹時すてに $\mathrm{P}$ 因子, $\mathrm{H}$ 因 子の存在した症例はそれぞれ18例 $(34 \%)$ と7例 (13.2\%) 存在し, 治瘉切除率は50.9\%であった(表 2 ). この他に N 因子により非治癒切除となったものが 1 例存在した。また53例中19例（35.8\%）に胃，小腸な どの臓器合併切除がなされていた．27例の治癒切除例 中, $\mathrm{P}$ 因子による再発は 4 例, H 因子による再発は 1 例であった。 また剖検例を含めて記載の明らかな59例 中, P因子および H 因子の出現した症例はそれぞれ26 例 $(44.1 \%) ， 11$ 例 $(18.6 \%) て ゙ あ り ，$ 腹膜播種の出現 頻度が高率であった. 自験例でも手術時には全くP因 子は存在せず，肝再発を重点に術後経過を見ていた。 しかし, 剖検時には腹腔全域を占める腹膜播種があり， あらためて本疾患における治療法の難しさを痛感し た. 化学療法も未だ確立されていないのが現状であ り 7)8), わわれも術後に種々の抗癌阂を用いたが有効 といえるものはなかった。今後は術中の予防的な抗癌 剤投与などを含めた治療法の確立が急務といえる。

低血糖発作はインスリノーマや副腎機能不全などて 
発現するが，近年になって腫場性低血糖（腫瘍随伴低 血糖症候群）とインスリン作用を有するIGF-II との関

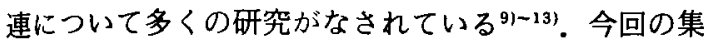
計では，低血糖症状を伴った大網悪性腫瘍は池田ら ${ }^{53}$ の報告例と自験例のみであった。自験例では血中イン

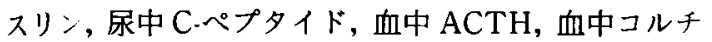
ソール，さらにはインスリングルカゴンの上位ホル モンであるソマトスタチンや, 血中の IGF-II も正常で あっだ(10)．われわれは腫瘍の消長が血糖值の増減と よく相関していることから，腫陽紏胞によるクルコー スそのものの消費が低血梼の原因でははいかと考えて いる。しかし, 自験例では腫瘍内の IGF-II またはIGF. II mRNA は末解析であること, 血中の IGF-II が正常 でも腫韵内の IGF-II 濃度が高值を示す場合もあるこ とから"11，IGF-II の関与が完全に否定されたかけでは ない.また,たとえ腫崵内のIGF-II が高值であっても， その結合タンパクやレセプターの変化など糖代謝全過 程にわたって複雑に関与して腫瘍性低血猜は惹起され ると言われている(1) 13). したがって, 低血糖症状を有 する腫崵症例では, 血中, 腫瘍内の IGF-II 測足, 血中 での結合タンパクや組織でのインスリンレセプターの 解析を行い, それらを集積していくことが腫瘍性低血 梼の病態を明らかにするために肝要なことと考えられ た.

\section{結 語}

低血糖症状を伴った大網原発肉腫の 1 例を報告する と共に, 本邦における大網肉腫症例の集積結果と腫瘍 性低血糖について考察した。

本論文の要旨は第58回日本臨床外科医学会総会 (京都)に おいて報告した。

\section{文献}

1) Elfving G, Hastbacka J : Primary solid tumors of the greater omentum. Acta Chir Scand 130 : $603-610,1965$

2) Weinberger HA, Ahmed MS: Mesenchymal solid tumors of the omentum and mesentery: Report of four cases. Surgery $82: 754-759,1977$
3）波頭経明, 田中千凱，伊藤隆夫他：大網平滑筋肉腫 の 1 例. 臨外 $43: 279-282,1988$

4）内山勝弘, 高田忠敬, 安田秀喜：巨大な大網平滑筋 肉腫の 1 例. 日臨外医会誌 $45: 1209-1214,1984$

5）池田 洋, 土川権三郎, 伊藤 元: 原発性大網平滑 筋肉腫の 1 剖検例。愛知医大医会誌 19：759766, 1991

6）岸本弘之, 梶谷真司, 沢田 隆他：大網平滑筋肉腫 の 2 例. 消外 $10: 1626-1630,1987$

7）末吉 晋, 车田 直, 松熊 晋他：咳を主訴として 発見された巨大な大網平滑筋肉腫の 1 切除例。日 臨外医会誌 $52: 177-182,1991$

8）鉄治, 古川敬芳, 谷口徹志他：大網平滑笳肉腫 の1例。日臨外医会誌 $54: 1648-1652,1993$

9) Luna AM, Wilson DM, Wibbelsman CJ, et al : Somatomedins in adolescence: A crosssectional study of the effect of puberty on plasma insulin-like growth factor I and II levels. J Clin Endocrinol Metab 57 : 268-271. 1983

10) Crosby SR, Anderton $C D$, Westwood M, et al: Measurement of insulin-like growth factor-II in human plasma using a specific monoclonal antibody-based two-site immunoradiometric assay. J Endocrinol 137 : 141-150, 1993

11) Shapiro ET, Bell GI, Polonsky KS, et al: Tumor hypoglycemia: Relationship to high molecular weight insulin-like growth factor-II. J Clin Invest 85 : 1672-1679, 1990

12) Stuart CA, Prince MJ, Peters EJ, et al: Insulin receptor proliferation: A mechanism for tumor-associated hypoglycemia. J Clin Endocrinol Metab 63: 879-885, 1986

13) M $\phi$ ller N, Blum WF, Mengel A, et al: Basal and insulin stimulated substrate metabolism in tumour induced hypoglycaemia; evidence for increased muscle glucose uptake. Diabetologia $34: 17-20,1991$ 


\title{
A CASE OF GREATER OMENTAL SARCOMA WITH HYPOGLYCEMIA
}

\author{
Shinsuke IYOMASA, Yasutaka MATSUZAKI, Masami KAWAI, Hiroyuki MATSUNAGA, \\ Yoko KODAMA and Yoshimasa YAMAGUCHI \\ Department of Surgery, Tsushima City Hospital
}

A 75-year-old man was admitted to the hospital because of hypoglycemia and an abdominal mass. The patient was diagnosed as having a greater omental tumor with liver metastasis by various examinations, and was operated on. Pathologically, the tumor was poorly differentiated sarcoma originated from the greater omentum with liver metastasis. The patient died of prominent peritoneal dissemination 17 months after the operation. Sixty cases including our case of malignant tumor origniated from the greater ometum have been reported in the past 16 years in Japan. Angiography was useful examination for the diagnosis of these tumors, and peritoneal dissemination occurred in $44.1 \%$ of those 60 cases.

In our case, serum IGF.II and other endocrinological factors were all within normal limits. However, since IGF-II in the tumor cells was not measured, a possibility that IGF-II had caused hypoglycemia is not completely excluded. 